\title{
POTENTIAL PRODUCTIVITY OF CUCUMBER AS AFFECTED BY IRRIGATION WATER AMOUNTS AND NITROGEN FERTILIZATION UNDER DRIP IRRIGATION AT NORTHWEST DELTA, EGYPT \\ El-Atawy, Gh. Sh. \\ Soils, Water and Environment Res. Ins., Agric. Res. Center, Giza, Egypt.
}

\begin{abstract}
Two field experiments with cucumber (Cucumis Sativus L.; var. Prince) were carried out during 2007 and 2008 growing seasons on sandy loam soil, at Wady Elnatroon, El-Behera governorate in Northwest Delta to investigate the most suitable irrigation water amount and nitrogen rates for cucumber grown under drip irrigation method. The treatments were arranged in a split plot design with four replicates. Four amounts of irrigation water were daily applied on a base of $100 \%, 90 \%, 80 \%$ and $70 \%$ of $\mathrm{ET}_{\mathrm{c}}$ with four nitrogen rates i.e. control, 50,100 and $150 \mathrm{~kg} \mathrm{~N} \mathrm{fed}^{-1}$.

Chief results indicated that cucumber yield were 18.357, 17.474, 14.660 and 12.820 ton fed. $^{-1}$ with irrigation water quantities $100 \%, 90 \%, 80 \%$ and $70 \%$ of $\mathrm{ET}_{\mathrm{c}}$, respectively. Irrigation with $100 \%$ of $\mathrm{ET}_{\mathrm{c}}$ and fertilized with $150 \mathrm{~kg} \mathrm{~N}$ produced the highest fruit yield $\left(23.221\right.$ ton $\mathrm{fed}^{-1}$.), while, the lowest fruit yield (8.003 ton fed ${ }^{-1}$.), obtained from control treatment which irrigated with $70 \%$ of $\mathrm{ET}_{\mathrm{c}}$.

The highest value of nitrogen use efficiency $\left(147.54 \mathrm{~kg}\right.$ fruits $\mathrm{kg}^{-1}$ applied N) was obtained under treatments of $100 \%$ of ETc with $50 \mathrm{~kg} \mathrm{~N} \mathrm{fed}^{-1}$. While, the lowest value $\left(9.30 \mathrm{~kg}\right.$ fruits $\mathrm{kg}^{-1}$ applied N) was obtained from $70 \%$ of ETc with $150 \mathrm{~kg} \mathrm{~N}$ fed. ${ }^{-1}$.

Amounts of irrigation water applied were $50.00,45.24,40.48$ and $35.71 \mathrm{~cm}$ for $100 \%, 90 \%, 80 \%$ and $70 \%$ of $\mathrm{ET}_{\mathrm{c}}$, respectively. Seasonal water consumption of cucumber was $44.54,40.16,35.96$ and $32.08 \mathrm{~cm}$ for irrigation treatments irrigated with $100 \%, 90 \%, 80 \%$ and $70 \%$ of $\mathrm{ET}_{\mathrm{c}}$, respectively. Irrigation with $90 \%$ of $\mathrm{ET}_{\mathrm{c}}$ enhanced crop growth and field water use efficiency of cucumber plants as compared to other treatments.

It could be concluded for obtaining a good cucumber yield and facing the irrigation water shortage, daily irrigation with $90 \%$ of $\mathrm{ET}_{\mathrm{c}}$ must be added with $150 \mathrm{~kg} \mathrm{~N}$ fed $^{-1}$.

Keywords: Cucumber, drip irrigation, $\mathrm{N}$ fertilization, water consumptive use, water use efficiency.
\end{abstract}

\section{INTRODUCTION}

Cucumber (Cucumis sativus L.) is one of major vegetable crops grown in Egypt for its fresh fruit. It is taken as fresh fruit or used as salads. In addition to its delicious taste and fairly good caloric value, it has high medicinal value for human beings. It is well known for natural diuretic and thus can serve as an active drug for secreting and promoting flow of urine. Due to high content of potassium (50-80 mg/100g), cucumber can highly be useful for both high and low blood pressures (Kadans, 1979). Increase in cucumber production like that of any other crop, can be achieved either bringing more area under cultivation, or by adopting improved varieties and better cultural practices. Management of irrigation water is one of the most 
important factors which influence the yield and quality of crops, water is necessary for every outgrowth processes in plants, therefore, water requirement should be achieved to reach a well controlled scientific use of water. Simsek et al. (2005) indicated that fruit yield was reduced significantly, as irrigation rate was decreased. Bao-Zhong et al. (2006) reported that the amount of irrigation water significantly affected plant growth and fruit production.

Application of the balanced needed fertilizers is one of the quickest and easiest ways of increasing yield per unit area. Nitrogen is considered as one of major nutrients required by the plants for growth, development and yield (Singh et al. , 2003; Watcharasak and Thammasak, 2005 and Jilani et al. , 2009). Osman et al. (2004) and Mahmoud et al. (2009) found a positive effect of all $\mathrm{N}$ treatments, over control regarding number of fruits and marketable yield in cucumber. Choudhari and More (2002) and Ahmed et al. (2007) reported that increasing the nitrogen application resulted in maximum fruit length, fruit weight, vine length and yield of cucumber. In view of importance of nitrogenous fertilizers, present research was undertaken to observe response of different nitrogen levels on growth and yield of cucumber.

The objective of the present study was to study the production potential of cucumber as affected by irrigation water amount and nitrogen rates using surface drip irrigation systems in Northwest Delta.

\section{MATERIALS AND METHODS}

Two field experiments were carried out during 2007 and 2008 growing seasons at Wady Elnatroon, El-Behera governorate to investigate the effect of irrigation amounts and nitrogen rates on cucumber yield as well as water consumptive use, amount of irrigation water applied and irrigation water use efficiency. The experimental field was fertilized by $10 \mathrm{~m}^{3}$ of chicken manure as well as $15 \mathrm{~kg} \mathrm{P}_{2} \mathrm{O}_{5}$ fed. $^{-1}$ under cucumber rows through soil preparation. The chicken manure contains $3.2 \% \mathrm{~N}, 2.1 \% \mathrm{P}$ and $1.3 \% \mathrm{~K}$.

Surface drip irrigation system used was consisted of normal polyethylene pipes of $16 \mathrm{~mm}$ diameter as laterals with in line dripper of $4 \mathrm{~L} / \mathrm{h}$ at $50 \mathrm{~cm}$ apart. The laterals were located $150 \mathrm{~cm}$ apart, one lateral for each plant row. Irrigation water was filtered through gravel filters and refiltered through screen filters. The soil of the experimental fields was sandy loam and it contained $11.85 \%$ clay, $13.70 \%$ silt and $74.45 \%$ sand. The average of soil electrical conductivity (soil paste extract) over 0-60 cm depth, was 0.68 $\mathrm{dSm}^{-1}$. The electrical conductivity of irrigation water was $1.1 \mathrm{dSm}^{-1} ; \mathrm{pH}$ of soil (1:2.5) was 7.5. The treatments were arranged in a split plot design with four replicates. The main plots were assigned with four irrigation water amounts and the sub plots were randomely assigned with four $\mathrm{N}$-fertilizer rates. The experiment size was 0.91 feddan included 64 rows with $150 \mathrm{~cm}$ apart and 40 $\mathrm{m}$ long.

Irrigation treatments were dialy applied with an amounts of water equal to $100 \%, 90 \%, 80 \%$ and $70 \%$ of the crop evapotranspiration $\left(\mathrm{ET}_{\mathrm{c}}\right)$. Nitrogen was applied as ammonium nitrate $(33.5 \% \mathrm{~N})$ at a rate of 0.0 (control), 50, 100 
and $150 \mathrm{~kg} \mathrm{~N}$ fed. ${ }^{-1}$ through the irrigation water using venture injection in ten equal doses, the first dose after 15 days from planting, while the later doses were applied on weekly basis.

Cucumber seeds of (Cucumis Sativus L.; var. Prince) was manually planted in one row in dry soil on 11 and 18 of July during the two successive seasons 2007 and 2008. The distance between hills was $50 \mathrm{~cm}$ and two plants/ hill. All field practices were done as usually recommended for cucumber cultivation. Harvesting was done after 30 days from planting. Central area of $45 \mathrm{~m}^{2}$ in each plot was kept for determining cucumber yield to eliminate any border effect. Fertilizer use efficiency by plants calculated as $\mathrm{kg}$ of total yield produced by each unit of fertilizers nutrients used.

\section{Soil water relations:}

Soil moisture content was determined gravimetrically in soil samples taken at successive of $15 \mathrm{~cm}$ each to a depth of $60 \mathrm{~cm}$ from three locations, under the emitter and between the emitters and the laterals. Soil samples were also collected just before irrigation and 6 hours after every irrigation as well as at harvesting to estimate evapotranspiration rates. Field capacity and the bulk density were determined to a depth of $60 \mathrm{~cm}$. The average values are presented in Table (1).

\section{1- Water consumptive use (Cu):}

Water consumptive use was calculated using the following equation (Hansin et al. 1979).

$$
\mathrm{Cu}=\sum_{\mathrm{i}=1}^{\mathrm{n}=4} \operatorname{Di} \times \mathrm{Bd} \times \theta_{2}-\theta_{1} / 100
$$

Where:

$$
\begin{array}{ll}
\mathrm{Cu} & =\text { Water consumptive use }(\mathrm{cm}) . \\
\mathrm{Di} & =\text { Soil layer depth }=15 \mathrm{~cm} . \\
\mathrm{Bd} & =\text { Soil bulk density, }\left(\mathrm{g} \mathrm{cm}^{-3}\right) \text { for this depth. } \\
\theta_{1} & =\text { Soil moisture } \% \text { before irrigation. } \\
\theta_{2} & =\text { Soil moisture } \% 6 \text { hours after irrigation. } \\
\mathrm{n} & =\text { Number of soil layers. }
\end{array}
$$

Table (1): Values of field capacity and bulk density for the two growing seasons.

\begin{tabular}{|c|c|c|c|c|}
\hline \multirow{2}{*}{$\begin{array}{c}\text { Soil } \\
\text { depth (cm) }\end{array}$} & \multicolumn{2}{|c|}{$\mathbf{2 0 0 7}$} & \multicolumn{2}{c|}{$\mathbf{2 0 0 8}$} \\
\cline { 2 - 5 } & $\begin{array}{c}\text { Field capacity } \\
\text { \% }\end{array}$ & $\begin{array}{c}\text { Bulk density } \\
\left(\mathbf{g ~ c m}^{-3}\right)\end{array}$ & $\begin{array}{c}\text { Field capacity } \\
\%\end{array}$ & $\begin{array}{c}\text { Bulk density } \\
\left(\mathbf{g ~ c m ~}^{\mathbf{3}} \mathbf{)}\right.\end{array}$ \\
\hline $0-15$ & 12.9 & 1.37 & 12.9 & 1.37 \\
$15-30$ & 12.9 & 1.37 & 12.9 & 1.37 \\
$30-45$ & 13.0 & 1.38 & 13.0 & 1.38 \\
$45-60$ & 13.0 & 1.38 & 13.0 & 1.38 \\
\hline
\end{tabular}

\section{Irrigation water applied (IWA):}

The amount of water applied at each irrigation was measured by flow meter and calculated according to Keller and Karmeli (1974) as follows: 
El-Atawy, Gh. Sh.

$$
I W A=\frac{E T o \cdot K c \cdot K r \cdot I I}{E a}+L R
$$

Where:

$$
\begin{array}{lll}
\mathrm{IWA}= & \text { irrigation water applied }(\mathrm{mm}) . \\
\mathrm{ET}_{0}= & \text { reference evapotranspiration }\left(\mathrm{mm} \text { day }{ }^{-1}\right) . \\
\mathrm{K}_{\mathrm{c}}= & \text { crop coefficient. } \\
\mathrm{K}_{\mathrm{r}}= & \text { reduction factor (Keller and Karmeli, 1974). } \\
\mathrm{II}= & \text { irrigation intervals (days). } \\
\mathrm{E}_{\mathrm{a}}= & \text { irrigation efficiency } \%=\mathrm{K}_{1} \times \mathrm{K}_{2}=0.85 . \\
\mathrm{K}_{1}= & \text { emitter uniformity coefficient }=0.95 . \\
\mathrm{K}_{2}= & \text { drip irrigation efficiency coefficient }=0.90 . \\
\mathrm{LR} & =\text { leaching requirements }\left(10 \% \text { of } \mathrm{ET}_{\mathrm{c}}\right) .
\end{array}
$$

Reference evapotranspiration ( $E T_{0}$ ) were estimated using penmanMonteith, and crop coefficient $\left(\mathrm{K}_{\mathrm{c}}\right)$ values for cucumber were taken as calculated by Allen et al. (FAO, 1998) values are shown in Table (2).

Table (2): Water requirements for cucumber plants grown on a sandy loam soil at Wady Elnatroon, El-Behera governorate (Drip irrigation).

\begin{tabular}{|l|c|c|c|c|}
\hline \multicolumn{1}{|c|}{ Months } & July & Aug. & Sept. & Oct. \\
\hline $\mathrm{ET}_{\circ} \mathrm{mm} \mathrm{d}^{-1}$ & 6.17 & 6.05 & 5.37 & 4.42 \\
${\text { Crop coefficient }\left(\mathrm{K}_{\mathrm{c}}\right)}_{\mathrm{ET}_{\mathrm{c}} \mathrm{mm} \mathrm{d}^{-1}}$ & 0.60 & 0.92 & 1.00 & 0.85 \\
& 3.70 & 5.57 & 5.37 & 3.76 \\
\hline
\end{tabular}

3- Irrigation water use efficiency (IWUE):

It was calculated as follows (Mao, 2003).

Where:

$$
\text { IWUE }=\frac{Y}{W R}
$$

$\mathrm{Y}=$ Fruit yield $\left(\mathrm{kg} \mathrm{feddan}^{-1}\right)$.

WR $=$ Total amount of water applied in the field $(\mathrm{cm})$.

\section{4- Crop water use efficiency (CWUE):}

It was calculated according to the following equation (Michael, 1978).

Where:

$$
\text { CWUE }=\frac{Y}{\mathrm{ETC}}
$$

CWUE = crop water use efficiency ( $\mathrm{kg}$ fruit $\mathrm{cm}^{-1}$ of water evapotranspiration).

$\mathrm{Y} \quad=$ Fruit yield $\left(\mathrm{kg} \mathrm{fed}^{-1}\right)$.

$\mathrm{ET}_{\mathrm{c}} \quad=$ evapotranspiration $(\mathrm{cm})$.

\section{5- Nitrogen use efficiency(NUE):}

Nitrogen use efficiency by plants was calculated as $\mathrm{kg}$ of the marketable yield produced by each unit of nitrogen fertilizers used. 


\section{Statistical analysis:}

All the data were statistically analysed following the procedure outlined to Snedecor and Cochran (1980). Combined analysis conducted for the data of the two growing seasons according to Cochran and Cox (1957). The differences between the mean values were compared by Duncan's Multiple Range Test (Duncan, 1955).

\section{RESULTS AND DISCUSSION}

\section{Total yield:}

Combined analysis of variance over the two growing seasons indicated that cucumber yield was significantly affected by irrigation water amounts and nitrogen rates as shown in Table (3).

Table (3): Mean values of cucumber fruit yield (ton fed..$^{-1}$ ) as influenced by irrigation water amounts and nitrogen rates under drip irrigation method in combined analysis of 2007 and 2008 seasons.

\begin{tabular}{|c|c|c|c|c|c|}
\hline \multirow[b]{2}{*}{ Variables } & \multicolumn{4}{|c|}{ Irrigation treatments } & \multirow[b]{2}{*}{ Mean } \\
\hline & $\begin{array}{l}100 \% \\
\text { of } E T_{c}\end{array}$ & $\begin{array}{l}90 \% \\
\text { of } \mathrm{ET}_{\mathrm{c}}\end{array}$ & $\begin{array}{l}80 \% \\
\text { of } E T_{c}\end{array}$ & $\begin{array}{c}70 \% \\
\text { of } E T_{c}\end{array}$ & \\
\hline N-rates in kg /fed. & & & & & \\
\hline Control & $11.234 \mathrm{~h}$ & $10.717 i$ & 9.006j & $8.003 \mathrm{k}$ & $9.735 \mathrm{D}$ \\
\hline 50 & $18.611 d$ & $17.001 \mathrm{e}$ & $14.123 \mathrm{~g}$ & $11.921 \mathrm{~h}$ & $15.414 \mathrm{C}$ \\
\hline 100 & $21.161 b$ & $20.396 c$ & $17.360 \mathrm{e}$ & $15.446 f$ & 18.591B \\
\hline 150 & $23.221 \mathrm{a}$ & $21.780 \mathrm{~b}$ & $18.151 d$ & $15.911 f$ & 19.766A \\
\hline Mean & $18.557 \mathrm{~A}$ & $17.474 \mathrm{~B}$ & $14.660 \mathrm{C}$ & 12.820D & \\
\hline
\end{tabular}

* Mean designated by the same letter is not significantly different at the $5 \%$ level according to Duncan's multiple range tests.

Exposing cucumber plants to water stress by watering every day with applied water equal $70 \%$ of $\mathrm{ET}_{\mathrm{c}}$ significantly decreased cucumber fruit yield by $30.9 \%$ as compared to daily watering with applied water equal $100 \%$ of $\mathrm{ET}_{\mathrm{c}}$. This increasing in cucumber fruit yield with increasing amount of applied water may be attributed to positive effect of more available moisture at vegetative growth processes. In this respect, Simsek et al. (2005) indicated that cucumber is a crop with high production potential when its requirements for growth and reproduction are met. Also, El-Hady and Wanas (2006) reported that $100 \%$ of $\mathrm{ET}_{\mathrm{c}}$ could produce higher yield and decreased water usage. These results are in harmony with those obtained by Ahmet et al. (2006), Bao-Zhong et al. (2006) and Ayotamuno et al. (2007).

Concerning nitrogen fertilization, data reveal that there was a significant increase in cucumber fruit yield with adding nitrogen up to $150 \mathrm{~kg}$ $\mathrm{N}$ fed. ${ }^{-1}$. The highest mean value of fruit yield (19.766 ton fed. $\left.{ }^{-1}\right)$ was obtained from fertilization with $150 \mathrm{~kg} \mathrm{~N}$ fed. ${ }^{-1}$. While, the lowest value of fruit yield (9.735 ton fed. ${ }^{-1}$ ) was obtained from untreated plants with nitrogen. This result may be explained that nitrogen plays a prominent role in building new merstimic cells, cell elongation, increasing photosynthesis activity and encouraging metabolic processes in cucumber plants. These results are in 
harmony with those of Osman et al. (2004), Bakar et al. (2006), Guler et al. (2006), Soltani et al. (2006), Ahmed et al. (2007), Waseem et al. (2008) and Jilani et al. (2009).

Data in Table 3 show that the average values of cucumber fruit yield were significantly affected by the interaction between irrigations treatments and nitrogen application rates, over both seasons. It is obvious form Table (3) that the highest mean value of fruit yield (23.221 ton fed. $\left.{ }^{-1}\right)$ was obtained from $100 \%$ of ETc with $150 \mathrm{~kg} \mathrm{~N} \mathrm{fed}^{-1}$. While, the lowest value of fruit yield (8.003 ton fed. ${ }^{-1}$ ) was obtained from $70 \%$ of ETc with untreated plants with nitrogen. These results are in harmony with those of Bakar et al. (2006), El-Hady and Wanas (2006), Guler et al. (2006) and Soltani et al. (2006).

\section{2: Nitrogen use efficiency:}

Nitrogen use efficiency (NUE) is one of the principal factors for saving fertilizer. There are many factors affected NUE. The data presented in Table (4) show the effect of irrigation regimes, nitrogen fertilizer levels and their interactions on nitrogen use efficiency in $\mathrm{kg}$ cucumber fruits $\mathrm{kg}^{-1} \mathrm{~N}$ fertilizer applied.

Table (4): Mean values of nitrogen use efficiency (NUE) in kg cucumber fruits $\mathrm{kg}^{-1}$ applied $\mathrm{N}$ fed. ${ }^{-1}$ as influenced by irrigation water amounts and nitrogen rates under drip irrigation in combined analysis of 2007 and 2008 seasons.

\begin{tabular}{|c|c|c|c|c|c|}
\hline \multirow[t]{3}{*}{ Variables } & \multicolumn{5}{|c|}{ Nitrogen use efficiency in kg cucumber fruits $\mathrm{kg}^{-1}$ applied $\mathrm{N}$} \\
\hline & \multicolumn{4}{|c|}{ Irrigation treatments } & \multirow{2}{*}{ Mean } \\
\hline & $100 \%$ of $E T$ & $90 \%$ of $\mathrm{ET}_{\mathrm{c}}$ & $80 \%$ of $E T_{c}$ & $70 \%$ of $\mathrm{ET}_{\mathrm{c}}$ & \\
\hline Control & & & ------- & & \\
\hline 50 & $147.54 a$ & $125.68 \mathrm{~b}$ & $102.34 \mathrm{c}$ & $78.36 \mathrm{~d}$ & $113.48 a$ \\
\hline 100 & $51.00 \mathrm{~g}$ & $67.90 f$ & $64.74 \mathrm{f}$ & $70.50 \mathrm{e}$ & $63.54 \mathrm{~b}$ \\
\hline 150 & $41.20 \mathrm{~h}$ & $27.68 \mathrm{i}$ & $15.82 \mathrm{j}$ & $9.30 \mathrm{k}$ & $23.50 \mathrm{c}$ \\
\hline Mean & $79.91 a$ & $73.75 b$ & $60.97 \mathrm{c}$ & $52.72 d$ & \\
\hline
\end{tabular}

* Mean designated by the same letter is not significantly different at the $5 \%$ level according to Duncan's multiple range tests.

Data in Table (4) indicate that nitrogen use efficiency of applied nitrogen was high significantly affected by irrigation regimes in the two seasons. The highest value of NUE (79.91 kg fruits $\mathrm{kg}^{-1}$ applied $\mathrm{N}$ fed. $\left.{ }^{-1}\right)$ resulted from cucumber plants irrigated with $100 \%$ of $\mathrm{ET}_{\mathrm{c}}$. Whereas, the lowest value of NUE (52.72 kg fruits kg ${ }^{-1}$ applied $\mathrm{N} \mathrm{fed}^{-1}$ ) obtained from irrigation with $70 \%$ of ETc. Concerning nitrogen fertilization, data reveal that there was a significant decrease in nitrogen use efficiency with adding nitrogen up to $150 \mathrm{~kg} \mathrm{~N}$ fed. $^{-1}$. The highest value of NUE $\left(113.48 \mathrm{~kg}^{-1}\right.$ fruits kg-1 applied N) obtained from fertilization with $50 \mathrm{~kg} \mathrm{~N}$ fed. ${ }^{-1}$ while, the lowest value (23.50 kg fruits $\mathrm{kg}^{-1}$ applied N) resulted from fertilization with $150 \mathrm{~kg} \mathrm{~N}$ fed. $^{-1}$ in the same seasons.

Data in Table (4) show that the average values of nitrogen use efficiency were high significantly affected by the interaction between irrigations treatments and nitrogen application rates, over both seasons. It is obvious from Table 4 that the highest mean values of NUE $(147.54 \mathrm{~kg}$ fruits 
$\mathrm{kg}^{-1}$ applied $\mathrm{N}$ fed. ${ }^{-1}$ ) was obtained from $100 \%$ of ETc with $50 \mathrm{~kg} \mathrm{~N}$ fed. ${ }^{-1}$, while, the lowest value $\left(9.30 \mathrm{~kg}\right.$ fruits $\mathrm{kg}^{-1}$ applied $\mathrm{N}$ ) was obtained from $70 \%$ of ETc with $150 \mathrm{~kg} \mathrm{~N}$ fed. ${ }^{-1}$. This may be due to nitrogen fertilizer translocation in the soil profile by mass flow with moisture distribution. High water amounts (100\% of ETc) led to good root system of cucumber and right fertilizer distribution, which increased FUE in the less amount. On the contrary high nitrogen fertilizer with the low water quantities had the low FUE due to the limited root system which related to less moist area. These results are in harmony with those obtained by El-Hady and Wanas (2006) and El-Atawy (2007)

II. Soil water relations:

1. Water consumptive use $(\mathrm{Cu})$ :

Evapotranspiration is the loss of water from plants and soil to the atmosphere. This process includes evaporation from the soil and plant surface plus transpiration of water from the plant. The values of water consumptive use as affected by irrigation treatments are presented in Table (5).

Table (5): Monthly and seasonal water consumptive use rates and water applied as affected by irrigation treatments and nitrogen rates for cucumber over both growing seasons under drip irrigation.

\begin{tabular}{|c|c|c|c|c|c|c|c|}
\hline \multirow{2}{*}{ Treatments } & \multirow{2}{*}{$\begin{array}{c}\mathrm{N}-\mathrm{rates} \\
\mathrm{kg} / \mathrm{fed}\end{array}$} & \multicolumn{4}{|c|}{ Monthly WCU rates } & \multirow{2}{*}{$\begin{array}{l}\text { Seasonal } \\
\text { rates }(\mathrm{cm})\end{array}$} & \multirow{2}{*}{$\begin{array}{c}\text { Water } \\
\text { applied }(\mathrm{cm})\end{array}$} \\
\hline & & July & Aug. & Sep. & Oct. & & \\
\hline \multirow{4}{*}{$\begin{array}{l}100 \% \\
\text { of } E T_{C}\end{array}$} & \begin{tabular}{|l|} 
Control \\
\end{tabular} & 6.49 & 16.50 & 17.34 & 3.81 & 44.14 & \multirow[t]{5}{*}{50.00} \\
\hline & 50 & 6.54 & 16.59 & 17.42 & 3.85 & 44.40 & \\
\hline & 100 & 6.58 & 16.69 & 17.52 & 3.89 & 44.68 & \\
\hline & & 6.63 & 16.78 & 17.59 & 3.93 & 44.93 & \\
\hline \multicolumn{2}{|c|}{ Average } & 6.56 & 16.64 & 17.47 & 3.87 & 44.54 & \\
\hline \multirow{4}{*}{$\begin{array}{l}90 \% \\
\text { of } E T_{C}\end{array}$} & Control & 6.10 & 14.91 & 15.06 & 3.71 & 39.78 & \multirow{5}{*}{45.24} \\
\hline & 50 & 6.16 & 14.98 & 15.13 & 3.78 & 40.05 & \\
\hline & 100 & 6.21 & 15.07 & 15.17 & 3.86 & 40.31 & \\
\hline & 150 & 6.25 & 15.12 & 15.20 & 3.93 & 40.50 & \\
\hline \multicolumn{2}{|c|}{ Average } & 6.18 & 15.02 & 15.14 & 3.82 & 40.16 & \\
\hline $80 \%$ & Control & 5.60 & 13.54 & 13.06 & 3.41 & 35.61 & \multirow{5}{*}{40.48} \\
\hline \multirow{3}{*}{ of $\mathrm{ET}_{\mathrm{C}}$} & 50 & 5.69 & 13.60 & 13.11 & 3.48 & 35.88 & \\
\hline & 100 & 5.75 & 13.64 & 13.14 & 3.56 & 36.09 & \\
\hline & 150 & 5.80 & 13.70 & 13.17 & 3.59 & 36.26 & \\
\hline \multicolumn{2}{|c|}{ Average } & 5.71 & 13.62 & 13.12 & 3.51 & 35.96 & \\
\hline & Control & 4.65 & 11.58 & 11.70 & 3.82 & 31.75 & \multirow[t]{5}{*}{35.71} \\
\hline \multirow{3}{*}{ of $\mathrm{ET}_{\mathrm{C}}$} & 50 & 4.71 & 11.65 & 11.78 & 3.86 & 32.00 & \\
\hline & 100 & 4.77 & 11.70 & 11.84 & 3.91 & 32.22 & \\
\hline & 150 & 4.79 & 11.74 & 11.88 & 3.93 & 32.35 & \\
\hline \multicolumn{2}{|c|}{ Average } & 4.73 & 11.67 & 11.80 & 3.88 & 32.08 & \\
\hline
\end{tabular}

Data in Table (5) show that the highest $(44.54 \mathrm{~cm})$ and the lowest $(32.08 \mathrm{~cm})$ mean of water consumptive use by cucumber plants were found with $100 \% \mathrm{ET}_{\mathrm{c}}$ and $70 \%$ of $\mathrm{ET}_{\mathrm{c}}$, respectively. This trend show that the increment in water consumptive use depends on the availability of soil moisture in the root zone. 
El-Atawy, Gh. Sh.

Monthly values of water consumptive use by cucumber plants were lower at the beginning of the growing season, and then increased as the plants grow up till it reached its peak in August. At the end of the season the rates declined as the crop matured. These results indicated that the increase in evapotranspiration rates goes parallel to the increase in the vegetative growth of cucumber plants. These findings agreed with Ahmet et al. (2006), Bao-Zhong et al. (2006) and El-Hady and Wanas (2006).

From Table (5), it can be noticed that there was a small increase in water consumption with adding nitrogen up to $150 \mathrm{~kg} \mathrm{~N}$ fed. ${ }^{-1}$. The increments were $1.79,1.81,1.83$ and $1.89 \%$ as compared to the control treatments with irrigation at $100,90,80$ and $70 \% \mathrm{ET}_{c}$, respectively. This could be attributed to that nitrogen promote growth of cucumber plants and accelerate the rate of transpiration. These findings are in agreement with these of El-Hady and Wanas (2006) and El-Atawy (2007).

\section{Irrigation water applied (IWA):}

Amounts of irrigation water applied throughout the two growing seasons under drip irrigation are showed in Table (5). Data revealed that the total amount of water applied under drip irrigation were 50.00, 45.24, 40.48 and $35.71 \mathrm{~cm}$, for $100 \%, 90 \%, 80 \%$ and $70 \%$ of ETc, respectively.

\section{Water use efficiency (WUE):}

The mean values of water use efficiency (WUE) as affected by irrigation treatments are tabulated in Table (6).

Table (6): Water use efficiency for cucumber under drip irrigation method (average of the two growing seasons).

\begin{tabular}{|c|c|c|c|c|}
\hline \multirow[b]{2}{*}{ Variables } & \multicolumn{4}{|c|}{ Drip irrigation treatments } \\
\hline & $\begin{array}{l}100 \% \\
\text { of }^{E} T_{c}\end{array}$ & $\begin{array}{r}90 \% \\
\text { of } \mathrm{ET}_{\mathrm{c}}\end{array}$ & $\begin{array}{l}80 \% \\
\text { of } \mathrm{ET}_{\mathrm{c}}\end{array}$ & $\begin{array}{l}70 \% \\
\text { of } \mathrm{ET}_{\mathrm{c}}\end{array}$ \\
\hline Cucumber fruit yield (kg/fed.) & 18557 & 17474 & 14660 & 12820 \\
\hline Irrigation water applied (cm.) & 50.00 & 45.24 & 40.48 & 35.71 \\
\hline Water consumption (ET) in $\mathrm{cm}$. & 44.54 & 40.16 & 35.96 & 32.08 \\
\hline $\begin{array}{l}\text { Irrigation water use efficiency ( } \mathrm{kg} \text { fruit yield } / \mathrm{cm} \\
\text { of water applied) }\end{array}$ & 371.1 & 386.3 & 362.2 & 359.0 \\
\hline Crop water use efficiency ( $\mathrm{kg}$ fruit yield/cm of ET) & 416.6 & 435.1 & 407.7 & 399.6 \\
\hline
\end{tabular}

Results indicated that the highest value of field and crop water use efficiency were recorded from the daily irrigation with $90 \%$ of $\mathrm{ET}_{\mathrm{c}}$, whereas, the lowest one was obtained from daily irrigation with $70 \%$ of $\mathrm{ET}_{\mathrm{c}}$. These results could be attributed to the significant differences among cucumber fruit yield, evapotranspiration and water applied values.

Irrigation and crop water use efficiency increased with decreasing of irrigation water applied up to $90 \%$ of $\mathrm{ET}_{\mathrm{c}}$, whereas, they decreased with 80 and $70 \%$ of $\mathrm{ET}_{\mathrm{c}}$ because of high decreasing of fruit yield of cucumber. Mao et al. (2003) reported that the water use efficiency (WUE) and irrigation water use efficiency (IWUE) decreased with the increase of irrigation water applied from stem fruiting to the end. These observations are in agreement with the data reported by Simsek et al. (2005) and El-Hady and Wanas (2006). 


\section{Conclusion}

Irrigation water and nitrogen had a positive effect on growth and yield of cucumber as it enhanced cucumber production. From this study we can recommend that under shortage of irrigation water, dialy irrigation with $90 \%$ of ETc and fertilization with $150 \mathrm{~kg} \mathrm{~N}$ per feddan for high cucumber fruit yield in sandy loam soils of Wady Elnatroon region, Egypt and the same conditions.

\section{REFERENCES}

Ahmed. N.; M. H. Baloch; A. Haleem; M. Ejaz and N. Ahmed (2007). Effect of different levels of nitrogen on the growth and production of cucumber. Life Sci. Int., J, (1):99-102.

Ahmet, E; S. Sensoy; I. Gedik and K. Kucukyumuk (2006). Irrigation scheduling based on pan evaporation values for cucumber (Cucumis sativus L.) grown under field conditions. Agric. Water Manag. ISSN 0378-3774vol. 81, no1-2, pp. 159-172

Allen, R.G.; L.S. Pereirs; D. Raes and M. Smith (1998). Crop evapotranspiration. Guidelines for computing crop water requirements. FAO irrigation and drainage, paper No. 56, FAO, Rome.

Ayotamuno, J. M.; K. Zuofa; O. A. Sunday and B. R. Kogbara (2007). Response of maize and cucumber intercrop to soil moisture control through irrigation and mulching during the dry season in Nigeria. African Journal of Biotechnology Vol. 6 (5), pp. 509-515.

Bakar. A.; M. S. Jilani and M. Iqbal (2006). Effect of different levels of NPK on the growth and yield of cucumber (Cucumis sativus L.) under the plastic tunnel in Multan. M. Sc. Thesis. Gomal Univ., Dera Ismail Khan.

Bao-Zhong; Y. Jie; K.Yaohu and S. Nishiyama (2006). Response of cucumber to drip irrigation water under a rainshelter. Agric. Water Manag. ISSN 0378-3774 vol. 81, no.1-2, pp. 145158.

Choudhari, S.M. and T.A. More (2002). Fertigation, fertilizer and spacing requirement of Tropical gynoecious cucmber hybrids. ISHS. Tsukuba, Japan. Acta Hort., 61: 588

Cochran, W.G. and G.M. Cox (1957). Experimental Designs. $2^{\text {nd }}$ Edit. pp. 611, John Wiley and Sons, Inc. New York.

Duncan, D.B. (1955). Multiple Range and Multiple F-Test Biometrics. 11:1-42.

El-Atawy, Gh. Sh. (2007). Irrigation and fertilization management under the conditions of Kafr El-Sheikh Governorate soil. Ph.D. Thesis, Soil Dept. Fac. of Agric., Mansoura Univ., Egypt.

El-Hady O.A. and Sh.A. Wanas (2006). Water and fertilizer use efficiency by cucumber grown under stress on sandy soil treated with acrylamide hydrogels. Journal of Applied Sciences Research, 2(12): 1293-1297

Guler, S.; H. Ibrikci and G. Buyuk (2006). Effect of different nitrogen rates on yield and leaf nutrient contents of drip-fertigated and green house grown cucumber. Asian. J. PI. Sci. 5(4):657-662.

Hansin, U. W.; O. W. Israelsen and Q. E. Stringharm (1979). Irrigation Principles and Practices. 4th (ed.). John Willey and Sons 
Jilani, M. S.; A. K. Waseem and M. Kiran (2009). Effect of different levels of NPK on the growth and yield of cucumber (Cucumis sativus) under the plastic tunnel. . Agric. Soc. Sci., Vol. 5, No. 3, : 99-101

Kadans, J. M. (1979). Encyclopedia of Medical Foods. Thorns Pub. Ltd., Willing Borough, North Ampotneshine U. J. Pp.92.

Keller J. and Karmeli D. (1974). Trickle irrigation design parameters. ASAE, 17 (4): 678-684.

Mahmoud, E.; N. Abd EL- Kader; P. Robin; N. Akkal-Corfini and L. Abd ElRahman (2009). Effects of different organic and inorganic fertilizers on cucumber yield and some soil properties. World J. Agric. Sci., 5 (4): 408-414.

Mao, X.; Liu m.; Wang X.; Liu Ch.; Hou Z. and Shi J. (2003). Effects of deficit irrigation on yield and water use of greenhouse grown cucumber in the North China Plain. Agric. Water Manage. Vol. 61, No.3, pp. 219-228.

Michael, A.M. (1978). Irrigation theory and practice. Vkas Publishing House PVT LTD New Delhi, Bombay.

Osman A. Sidahmed; M. S. Al Rawahi and F.S. Al Raisy (2004). Response of cucumber (Cucumis sativus L.) to nitrogen fertigation under plastic house conditions. Sudan J. of Agric. Res. Vol. 4: 13-19.

Simsek, M.; T.Tonkaz; M. Kacira; N. Cömlekcioglu and Z. Dogan (2005). The effects of different irrigation regimes on cucumber (Cucumis sativus L.) yield and yield characteristics under open field conditions. Agric. Water Manage.Vol. 73, Issue 3, Pp173-191.

Singh, S. S.; P. Gupta and A. K. Gupta (2003). Handbook of Agricultural Sciences. Kalyani Publishers, New Delhi, India. pp. 184- 185.

Snedecor, G.W. and W.G. Cochran (1980). Statistical methods. $7^{\text {th }}$ edition lowa State Univ. Press. Ames. lowa, U.S.A.

Soltani, R.; A. Kashi and M. Babalar (2006). Effect of nitrogen form on yield, fruit number and leaf nutrient content of two greenhouse cucumber cultivars in soil-less culture. Acta Horticulture, 731. Third International Symposium on Cucurbits,

Watcharasak, S. and T. Thammasak (2005). Effect of nitrogen and potassium concentration in fertigation on growth and yield of cucumber. Kamphaengsaen Acad. J., 3: 18-29

Waseem, K.; Q.M. Kamran and M.S. Jilani (2008). Effect of different levels of nitrogen on the growth and yield of Cucumber (Cucumis sativus L.). J. Agric. Res., 46: 259-266. 
القـارة الإتتاجيـة لمحصــول الخيـار تحـت تـأثير كميـات الـري بـالتثقيط والتسـميد

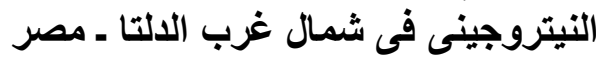

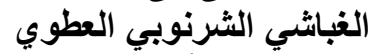

معهذ بحوث الأراضيى والمياهي والبيئة ـ مركز البحوث الزراعية ـ الجيزة ـ مصر

أجريت هذه الدر اسة بمنطقة وادى النطرون, محافظة البحيرة خلال موسمي الزر اعة 2007

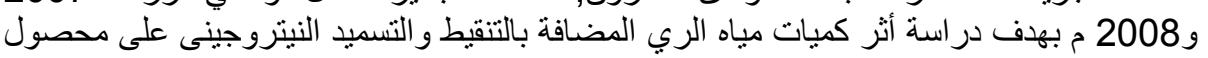

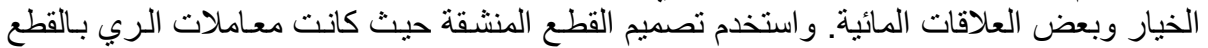

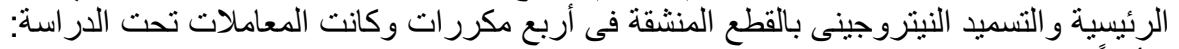

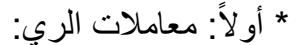

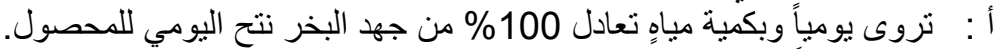

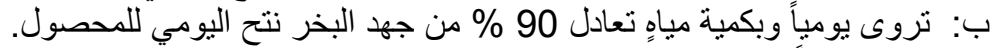

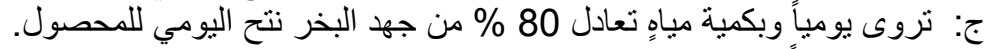
د : تروى يومياً وبكمية ميامٍ تعادل 70 \% من من جهد البخر نتح اليومي للمحصول.

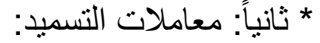

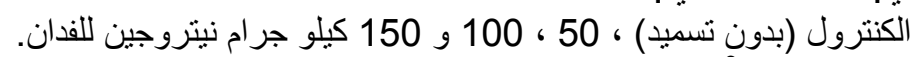

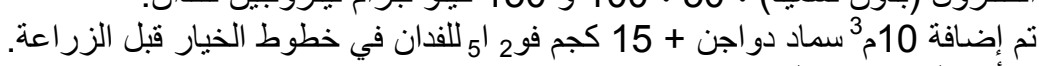

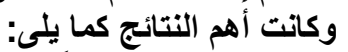
1- أدى الري يومياً وبكمية مياهٍ تعادل 100\% من جهد البخر نتح اليومي للححصول إلى زيادةٍ

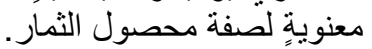

2- أدت إضِافة النبتروجين حتى 150 كيلو جرام نيتروجين للفدان إلى الحصول على أعلى القيم

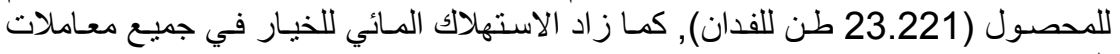

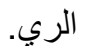

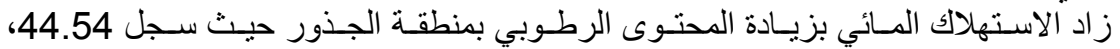

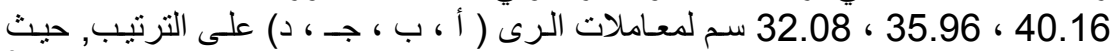

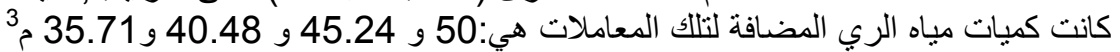

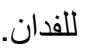
أدى الري وبكمية مياه تعادل 90\% من جها البخر نتح اليومي للمحصول إلى زيادة كفاءة

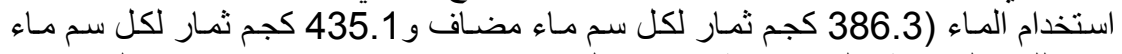

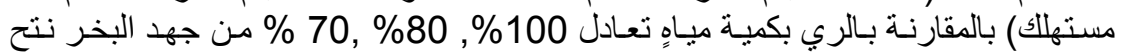

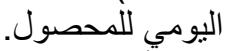

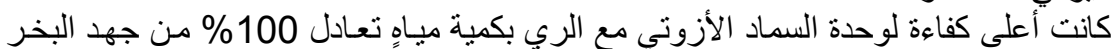

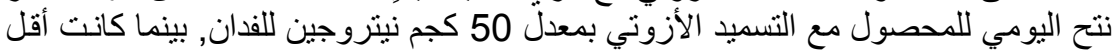

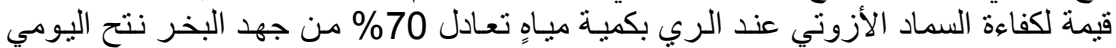

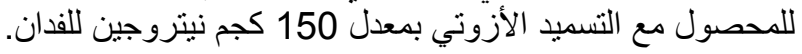

كلية الزراعة - جامعة المنصورة

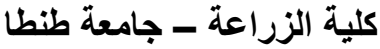

قام بتحكيم البحث

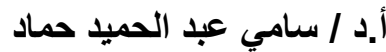

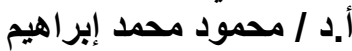

